\title{
Nursing in Brazil: socioeconomic analysis with a focus on the racial composition
}

\author{
Enfermagem no Brasil: análises socioeconômicas com foco na composição racial \\ Enfermería en Brasil: análisis socioeconómicas con enfoque en la composición racial
}

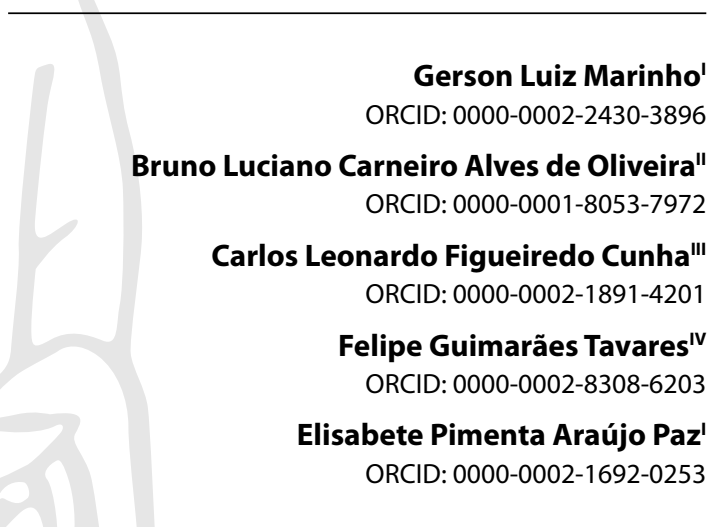

'Universidade Federal do Rio de Janeiro. Rio de Janeiro, Rio de Janeiro, Brazil.

"Universidade Federal do Maranhão. São Luís, Maranhão, Brazil.

I'Universidade Federal do Pará. Belém, Pará, Brazil.

"Universidade Federal Fluminense. Niterói, Rio de Janeiro, Brazil.

How to cite this article: Marinho GL, Oliveira BLCA, Cunha CLF, Tavares FG, Paz EPA. Nursing in Brazil: socioeconomic analysis with a focus on the racial composition. Rev Bras Enferm. 2022;75(2):e20201370. https://doi.org/10.1590/0034-7167-2020-1370

\section{Corresponding author:}

Gerson Luiz Marinho

E-mail: gersonmarinho@gmail.com

EDITOR IN CHIEF: Dulce Barbosa ASSOCIATE EDITOR: Hugo Fernandes

Submission: $12-23-2020$

Approval: 05-09-2021

\section{ABSTRACT}

Objectives: to analyze the socioeconomic characteristics of nurses and nursing technicians living in Brazil according to color/race. Methods: based on the 2010 Demographic Census sample, 62,451 nursing professionals (nurses and technicians) living in Brazil were selected. Differences in monthly income were estimated by multivariate models, stratified by color or race groups (white, brown, and black). Results: the majority were technicians (61.9\%) of white color (54.3\%). The income of white nurses exceeded that of brown and black nurses by more than a quarter; among technicians, white professionals had an income approximately $11 \%$ higher than brown and black nurses. Conclusions: differences between incomes of nursing workers were associated with ethnic/racial background, revealing situations in which white professionals systematically presented more favorable job and income conditions than black and brown professionals.

Descriptors: Nursing Staff; Socioeconomic Factors; Racial Factors; Occupational Groups; Censuses.

\section{RESUMO}

Objetivos: analisar características socioeconômicas de enfermeiros e técnicos de enfermagem residentes no Brasil segundo cor/raça. Métodos: com base na amostra do Censo Demográfico 2010, foram selecionados 62.451 profissionais de enfermagem (enfermeiros e técnicos) residentes no Brasil. Diferenças da renda mensal foram estimadas por modelos multivariados, estratificados por grupos de cor ou raça (branca, parda e preta). Resultados: a maioria eram técnicos $(61,9 \%)$ de cor branca (54,3\%). A renda de enfermeiros brancos superou em mais de $1 / 4$ a dos pardos e pretos; entre os técnicos, brancos tinham renda aproximadamente $11 \%$ maior do que a de pardos e pretos. Conclusões: diferenças entre rendimentos dos trabalhadores da enfermagem estavam associadas ao pertencimento étnico-racial, revelando situações nas quais profissionais de cor/raça branca apresentaram, sistematicamente, condições mais favoráveis de trabalho e renda, em relação aos pretos e pardos.

Descritores: Recursos Humanos de Enfermagem; Fatores Socioeconômicos; Fatores Raciais; Categorias de Trabalhadores; Censos.

\section{RESUMEN}

Objetivos: analizar características socioeconómicas de enfermeros y técnicos de enfermería residentes en Brasil segundo color/raza. Métodos: con base en la muestra del Censo Demográfico 2010, fueron seleccionados 62.451 profesionales de enfermería (enfermeros y técnicos) residentes en Brasil. Diferencias de la renta mensual fueron estimadas por modelos multivariados, estratificados por grupos de color o raza (blanca, mestiza y negra). Resultados: la mayoría eran técnicos $(61,9 \%)$ de color blanca (54,3\%). La renta de enfermeros blancos superó en más de $1 / 4 \mathrm{a}$ de los mestizos y negros; entre los técnicos, blancos tenían renta aproximadamente $11 \%$ mayor que la de mestizos y negros. Conclusiones: diferencias entre rendimientos de los trabajadores de la enfermería estaban relacionadas al pertenecer étnico-racial, revelando situaciones en las cuales profesionales de color/raza blanca presentaron, sistemáticamente, condiciones más favorables de trabajo y renta, en relación a los negros y mestizos.

Descriptores: Personal de Enfermería; Factores Socioeconómicos; Factores Raciales; Grupos Profesionales; Censos. 


\section{INTRODUCTION}

In most countries, including Brazil, nursing professionals represent the category with the largest contingent of people among all workers in the health sector ( $>50 \%$ of the total) ${ }^{(1)}$. This segment includes nurses, nursing technicians, nursing assistants, obstetricians, midwives, and other self-employed professionals. Although there is a debate about professional identities in various situations and using jargon, the population identifies nursing through a single category: nurses ${ }^{(2-4)}$.

Despite the expressive representativeness of nursing professionals in Brazil, there are few analyses on demographic and socioeconomic dynamics based on nationally representative data ${ }^{(5-6)}$. When considering the totality of nursing workers, only one-third of this total is composed of graduates from college-level courses - nursing undergraduate courses (from now on referred to as "nurses") (5). Even less is known about mid-level professionals' dynamics and sociodemographic composition (nursing technicians), except for the evidence that indicates precarious working conditions, low salaries, and numerous difficulties to perform work activities ${ }^{(6-7)}$. Other studies have examined the formation of professional identity of nurses in light of Brazilian historical contexts, presenting elements on social origin, educational opportunities, gender, and racial-ethnic composition ${ }^{(2,4)}$; however, the analyses prioritized qualitative designs.

According to the censuses conducted in 2000 and 2010, nursing professionals living in Brazil grew at a rate of 3.1\% per year, a rate almost three times higher than the population growth of the entire country $\left(1.2 \%\right.$ per year) ${ }^{(8)}$. More expressively, the increase in the number of nursing technicians (4.5\% per year) and nurses (13.4\% per year.) was reflected in changes in sociodemographic profiles, with an increase of professionals identified as brown and black in the questionnaire on ethnic-racial classification ${ }^{(5,8)}$. The significant increase in the number of nurses may have resulted from the expansion of higher education courses throughout the country(5,9). However, the vertiginous growth of university courses, primarily private, was not reflected in improved income levels; on the contrary, socioeconomic inequalities between nursing technicians and nurses increased ${ }^{(7)}$. The hypothesis is that the search for opportunities to work as a nurse overlaps with the offer of vacancies in the labor market, which directly impacts the socioeconomic conditions ${ }^{(5,7)}$.

It is essential to mention that analyses of living and working conditions carried out for specific professional categories reflect historical and political conjunctures that characterize countries at a given time. In the Brazilian case, the socioeconomic characteristics of workers are determined by several aspects, among which we highlight: regional diversity (given the continental dimensions of Brazil, living conditions are influenced by the particularities of geographical regions), income distribution (remuneration and employment ties) and population composition according to gender, age and racial background ${ }^{(10-11)}$. Thus, the Brazilian scenario presents inequalities that systematically point to less favorable working conditions for women, blacks (black and brown), and residents of the North and Northeast regions ${ }^{(10-13)}$.

Norms that impose hierarchical relationships regulate the job of nurses and nursing technicians, defined by the qualification obtained according to the years of study. Nurses are required to complete higher education. In contrast, nursing assistants and technicians can act after high school completion ${ }^{(7,14)}$. Nevertheless, there is a hypothesis that the demographic and socioeconomic phenomena and the dynamics of the labor market experienced by nursing professionals are not restricted only to the technical attributions and skills intrinsic to professional competencies ${ }^{(5,14)}$.

The socioeconomic inequalities and differences in working conditions observed in population groups defined based on color or race categories are intensely discussed in sociological studies ${ }^{(11-13)}$. In general, the arguments are based on historical events presented in perspective with different political scenarios that influenced labor market dynamics in the past ${ }^{(4,12)}$. In the field of racial inequalities, socioeconomic and labor conditions are analyzed considering aspects related to education levels and educational qualifications, with emphasis on opportunities for access to higher education ${ }^{(13)}$.

Sociodemographic analyses of specific occupations, focusing on color/race groups, are infrequently performed and limited in their conclusions ${ }^{(5-6)}$. On the one hand, part of the limitations stems from the scarcity of representative data sources and a terminological diversity of occupational categories, which makes it difficult to make comparisons over time $\mathrm{e}^{(5-6)}$. On the other hand, data collected by demographic censuses are representative of the entire country and are an essential tool for the study of specific demographic dynamics of various population groups ${ }^{(15)}$.

Demographic censuses provide subsidies for implementing and evaluating public policies and assessing socioeconomic and demographic profiles of specific groups, in which professional categories are included, such as nursing professionals ${ }^{(15-16)}$. According to the 2010 Demographic Census conducted in Brazil, the monthly per capita income of the white population was $85 \%$ higher than black people and $82 \%$ higher than brown people $\left(\mathrm{R} \$ 1,535.47, \mathrm{R} \$ 832.25\right.$, and $\mathrm{R} \$ 843.87$, respectively) ${ }^{(8)}$. In addition, people of white color or race also had a higher literacy rate $(92.8 \%)$ than black $(81.6 \%)$ and brown $(82.8 \%)^{(8)}$.

\section{OBJECTIVES}

To analyze nursing professionals' racial composition characteristics and income conditions in Brazil based on data from the latest demographic census conducted in 2010.

\section{METHODS}

\section{Ethical aspects}

The data source was the Demographic Census Sample carried out by the Brazilian Institute of Geography and Statistics (IBGE) with decennial periodicity. The data are public domain and free access, made available for download by government agencies. There is no identification of the people interviewed, and the results must be generated in an aggregated manner.

In line with current Brazilian regulations on human research ethics, surveys conducted with secondary data and maintaining the anonymity of the investigated do not need to be submitted to a Research Ethics Committee (Resolution 466/2012 CONEP). Additionally, access to public data collected by government agencies is supported by the Lei de Acesso à Informação (Access to Information Law) (Lei 12.527/2011). 


\section{Design, period, and place of study}

The cross-sectional study (survey type) was conducted based on data from the 2010 Demographic Census Sample, operationalized throughout Brazil by IBGE. The data are publicly accessible, free of charge and available for download (http://www.ibge.gov.br).

In Brazilian censuses, occupations are investigated according to criteria defined by the Brazilian Classification of Occupations, structured according to recommendations of the International Labor Organization, with definitions based on the International Standard Classification of Occupations ${ }^{(17)}$. In 2010, people aged ten or older selected by the Census sample and who had some occupation were surveyed for the variable "Occupation in the main job" (code V6461), and more than 500 occupational categories were identified, grouped into ten main groups, among which is the group "Health occupations"(17).

\section{Population; criteria of inclusion and exclusion}

This study took into consideration two categories of the variable "occupation," namely, "Nursing professionals" [code 2221] and "Mid-level nursing professionals" [code 3221]. The criteria for defining the population of nurses were: all persons identified as "Nursing professionals" aged 21 years or older who had completed higher education. The population of nursing technicians was defined as all persons in the category "Mid-level nursing professionals" who were aged 21 years or older and had at least completed high school as the highest level of education.

In the 2010 Census, the question "What is your color or race?" (V0604) identified all residents of households using self-identification in the categories "white," "black," "yellow," "brown," and "native"(17). This study did not include nursing professionals identified as yellow and indigenous because they represent less than $1 \%$ of the total.

Thus, the estimates were generated for a total of 62,451 nursing professionals living in Brazil, 22,556 of whom were nurses (36.1\%) and 39,895 nursing technicians (63.9\%). The professionals were characterized according to gender, age, marital status, nature of the job (public or private sector), number of jobs, and total monthly income per capita (analyzed continuously and in minimum wage ranges). It is worth pointing out that, on the reference date of data collection for the 2010 Census (July 31,2010), a minimum wage in Brazil was equivalent to $R \$ 510.00^{(17)}$. A decade later, in the middle of 2020, the value of the minimum wage was $R \$ 1,039.00$. Over this period, the purchasing power of products and services was reduced by $12 . \%^{(18)}$. The analyses were stratified according to categories of color or race white, brown, and black.

\section{Study protocol}

The regional distribution of nursing professionals was presented according to categories of color or race, according to the median monthly income recorded for all nurses $(R \$ 1,700.00)$ and nursing technicians $(\mathrm{R} \$ 1,000.00)$ throughout the country. According to the geographic regions (North, Northeast, Southeast, South, and Central-West), the results identify proportions of nurses and nursing technicians with monthly incomes below the median income (for the total of professionals) according to categories of color or race.
According to color or race groups, variations between the monthly incomes of nurses and nursing technicians were verified using box-plots; and comparisons of monthly incomes among whites, browns, and blacks were verified using non-parametric statistical tests (Kruskal-Wallis), considering nurses and technicians independently.

Focusing on the total monthly income per capita reported by the professionals, multivariate statistical models were generated to analyze factors associated with differences in income reported by nurses and nursing technicians according to color or race categories. The assumption of normal distribution of the variable "total per capita monthly income" was verified using the Shapiro-Wilk test, whose normality hypothesis was rejected, so we proceeded to its log transformation. "Log transformation" is a strategy often recommended for asymmetric data, such as monetary measures and specific biological and demographic measures ${ }^{(19)}$.

The writing of the manuscript followed the recommendations of the STROBE (Strengthening the Reporting of Observational Studies in Epidemiology) strategy for developing the dissemination of observational study results ${ }^{(20)}$.

\section{Analysis of results and statistics}

According to categories of racial background, the study analyzed inequalities per capita in the monthly income (dependent variable) of nurses and nursing technicians employing the calculation of coefficients generated through simple linear regression and adjusted for the selected characteristics (independent variables). The effects of racial classification on monthly income were read and interpreted by estimating the exponentiated coefficients (log of income), from which one unit was subtracted and multiplied by $100^{(19)}$. So, we obtained the percentage of decrease in the income level for each increase in the unit of the independent variable concerning the reference color or race category (white). For example: if the coefficient indicates the value -0.198 , it is derived that $\exp (-0.198)-1)) * 100=-18.0 \%$.

In all steps, effects of the census sampling plan (complex sampling performed in multiple stages and use of individual weights) ${ }^{(17)}$ were incorporated, and differences were considered statistically significant up to the $5 \%$ level, including the absence of overlapping $95 \% \mathrm{Cls}$. The analyses were performed with the support of the Stata ${ }^{\circledast}$ software survey package (version 14, Stata Corp., College Station, United States).

\section{RESULTS}

In 2010, the population of nursing professionals living in Brazil was estimated at approximately 722 thousand people, represented mainly through nursing technicians $(61.9 \% ; 95 \% \mathrm{Cl}$ 61.4-62.4). Overall, most nursing professionals were classified as white in the question of color or race $(54.3 \%$; $95 \% \mathrm{Cl} 53.8-54.8)$, followed by brown $(35.2 \%$; $95 \% \mathrm{Cl} 34.7-35.7)$ and black (10.5\%; 95\% Cl 10.2-10.9).

Nationwide, the population of nurses was estimated at 274.8 thousand people, with the majority classified as white in the question about color or race $(62.7 \% ; 95 \% \mathrm{Cl} 61.9-63.5)$, followed by brown (29.4\%; 95\%Cl 28.6-30.2) and black (7.9\%; 95\%Cl 7.4-8.4). Table 
1 shows the demographic and socioeconomic characteristics of the nurses, with a large majority belonging to the female gender (> 80\%), ages less than 40 years ( $>60 \%)$, and single marital status (>40\%) (Table 1). Note that there were no differences in the comparison between the three categories of color or race.

As for working conditions and income, most nurses (> 60\%) were employed in the private sector, supported by labor laws guaranteed in the Consolidação das Leis Trabalhistas (Consolidation of Labor Laws) (CLT). It is noteworthy that the highest proportions of nurses working in the public sector were brown and black skin color or race ( $23.4 \%$ and $22.7 \%$, respectively). Likewise, among the brown and black nurses, the highest proportions had more than one job ( $18.5 \%$ and $20.7 \%$, respectively). As for income ranges (in minimum wages), there are similar distributions between brown and black nurses, with approximately $1 / 3$ having a total income (all jobs) of less than two minimum wages (less than $\mathrm{R} \$ 1,100.00$ ) at the time of the census. On the other hand, one in three white nurses had income equal to or higher than five minimum wages (33.9\%; 95\%Cl 32.8-35.0) (Table 1).

Table 2 presents sociodemographic characteristics of nursing technicians. With a total population estimated at 447.3 thousand people, most were classified as white $(49.1 \%$; $95 \% \mathrm{Cl} 48.5-49.7)$, followed by brown (38.8\%; 95\%Cl 38.2-39.4) and black (12.1\%; $95 \% \mathrm{Cl} 11.7-12.6)$. The demographic profiles are similar to those observed in nurses, characterized by similarities in comparisons between the categories of color or race. As shown in Table 2, the vast majority of nursing technicians were female ( $>80 \%$ ), aged less than 40 years (> 55\%). Regarding marital status, most of the white technicians were married $(43.4 \%$; $95 \% \mathrm{Cl} 42.5-44.3)$, while among brown and black people, the largest contingents were single (45.8\% and $51.1 \%$, respectively) (Table 2 ).

Concerning the characteristics that describe the working conditions and income, most nursing technicians were linked to the private sector, supported by the Consolidation of Labor Laws (CLT) (>60\%). Black technicians had the lowest proportion of ties with the public sector $(17.8 \% ; 95 \% \mathrm{Cl} 16.3-19.4)$ and the highest contingent of professionals with two or more jobs $(16.3 \% ; 95 \% \mathrm{Cl}$ 14.8-18.0). In the stratifications according to income ranges, most brown and black nursing technicians had a total monthly income below two minimum wages $(54.7 \%$ [95\% Cl 53.7-55.7]; and $52.1 \%$ [95\% Cl 49.9-54.2], respectively) (Table 2).

Figures 1.a) and 1.b) represent the regional distribution of nursing professionals in Brazil, identifying the population contingents with the lowest monthly income (population whose monthly income was lower than the median value).

In the case of nurses (Figure 1.a), it is possible to observe a pattern in which white color or race presented the lowest proportions of professionals with the lowest incomes, ranging from $29.1 \%$ $(95 \% \mathrm{Cl} 24.5-34.2)$ in the North region to $44.9 \%(95 \% \mathrm{Cl} 42.6-47.1)$ in the South region. In the Southeastern and Southern regions, most brown nurses had a monthly income below $\mathrm{R} \$ 1,700.00$, reaching $62.3 \%$ of the total brown nurses, i.e., only one in three brown nurses had an income above $\mathrm{R} \$ 1,700.00$, which at the time represented a little more than three minimum wages. Except for the South, in all regions, the highest proportions of black nurses with incomes below the median were registered, ranging from $37.6 \%(95 \% \mathrm{Cl} 25.6-51.4)$ in the North to $55.7 \%$ (95\%Cl 51.4-59.9) in the Southeast (Figure 1.a).

Table 1 - Socioeconomic and demographic characteristics of nurses according to color/race groups interviewed in the 2010 Brazilian Demographic Census

\begin{tabular}{|c|c|c|c|c|c|c|c|c|}
\hline & \multicolumn{8}{|c|}{ Nurses by color or race } \\
\hline & \multicolumn{2}{|c|}{ White $(n=14,431)$} & \multicolumn{2}{|c|}{ Brown $(n=6,586)$} & \multicolumn{2}{|c|}{ Black $(n=1,539)$} & \multicolumn{2}{|c|}{ Total $(\mathrm{N}=\mathbf{2 2 , 5 5 6 )}$} \\
\hline & $\%$ & (IC95\%) & $\%$ & IC95\% & $\%$ & IC95\% & $\%$ & IC95\% \\
\hline \multicolumn{9}{|l|}{ Gender } \\
\hline Male & 14.8 & $(14.1-15.6)$ & 15.3 & $14.2-16.4$ & 16.6 & $14.3-19.3$ & 15.1 & $14.5-15.7$ \\
\hline Female & 85.2 & (84.4-85.9) & 84.7 & $83.6-85.8$ & 83.6 & $80.7-85.7$ & 84.9 & $84.3-85.5$ \\
\hline \multicolumn{9}{|l|}{ Age Group } \\
\hline 21 to 29 & 33.3 & $(32.3-34.3)$ & 30.9 & $29.5-32.4$ & 22.5 & $19.9-25.3$ & 31.7 & $30.9-32.5$ \\
\hline 30 to 39 & 32.9 & (31.9-33.9) & 34.8 & $33.3-36.4$ & 33.6 & $30.5-36.9$ & 33.5 & $32.7-34.3$ \\
\hline 40 to 49 & 20.7 & (19.8-21.6) & 21.5 & $20.2-22.8$ & 24.6 & $21.8-27.6$ & 21.2 & $20.5-22.0$ \\
\hline 50 to 59 & 10.8 & $(10.2-11.6)$ & 10.2 & $9.2-11.2$ & 15.7 & 13.4-18.4 & 11.0 & $10.5-11.6$ \\
\hline$\geq 60$ & 2.3 & $(2.0-2.7)$ & 2.6 & $2.1-3.3$ & 3.6 & $2.5-5.0$ & 2.5 & $2.2-2.8$ \\
\hline \multicolumn{9}{|l|}{ Marital Status } \\
\hline Married & 41.9 & $40.8-43.0$ & 39.2 & $37.6-40.8$ & 38.7 & $35.4-42.0$ & 40.9 & $40.0-41.7$ \\
\hline Single & 46.1 & $45.1-47.2$ & 49.7 & $48.1-51.3$ & 48.2 & $44.9-51.6$ & 47.3 & $46.5-48.2$ \\
\hline Separated/Divorced & 9.9 & $9.2-10.6$ & 9.0 & $8.1-9.9$ & 10.5 & $8.6-12.8$ & 9.7 & $9.1-10.2$ \\
\hline Widow (er) & 2.1 & $1.2-2.4$ & 2.2 & $1.8-2.8$ & 2.6 & $1.8-3.8$ & 2.2 & $1.9-2.4$ \\
\hline \multicolumn{9}{|l|}{ Nature of the job } \\
\hline Private (CLT\#) & 67.4 & $66.3-68.4$ & 60.6 & $59.1-62.1$ & 65.8 & $62.5-68.9$ & 65.3 & $64.4-66.1$ \\
\hline Public & 20.5 & $19.7-21.4$ & 23.4 & $22.1-24.8$ & 22.7 & $20.0-25.7$ & 21.6 & $20.9-22.3$ \\
\hline Others (não CLT) & 12.1 & $11.4-12.8$ & 16.0 & $14.9-17.1$ & 11.5 & $9.5-13.8$ & 13.2 & $12.6-13.8$ \\
\hline \multicolumn{9}{|l|}{ № of jobs } \\
\hline One & 82.3 & $81.4-83.2$ & 81.5 & $80.1-82.7$ & 79.3 & $76.5-82.0$ & 81.8 & $81.1-82.5$ \\
\hline Two & 17.7 & $16.8-18.6$ & 18.5 & $17.3-19.9$ & 20.7 & $18.0-23.6$ & 18.2 & $17.5-18.9$ \\
\hline \multicolumn{9}{|l|}{ Income Ranges (MW*) } \\
\hline$<2 \mathrm{MW}$ & 22.7 & 21.9-23.6 & 30.5 & $29.1-31.9$ & 31.9 & $29.0-35.0$ & 25.7 & $25.0-26.5$ \\
\hline$\geq 2$ and $<5 \mathrm{MW}$ & 43.4 & $42.3-44.5$ & 42.3 & $40.7-43.9$ & 43.0 & $39.7-46.4$ & 43.0 & $42.2-43.9$ \\
\hline$\geq 5 \mathrm{MW}$ & 33.9 & $32.8-35.0$ & 27.2 & $25.8-28.8$ & 25.0 & $22.2-28.2$ & 31.2 & $30.4-32.1$ \\
\hline
\end{tabular}


Table 2 - Socioeconomic and demographic characteristics of nursing technicians according to color/race groups interviewed in the 2010 Brazilian Demographic Census

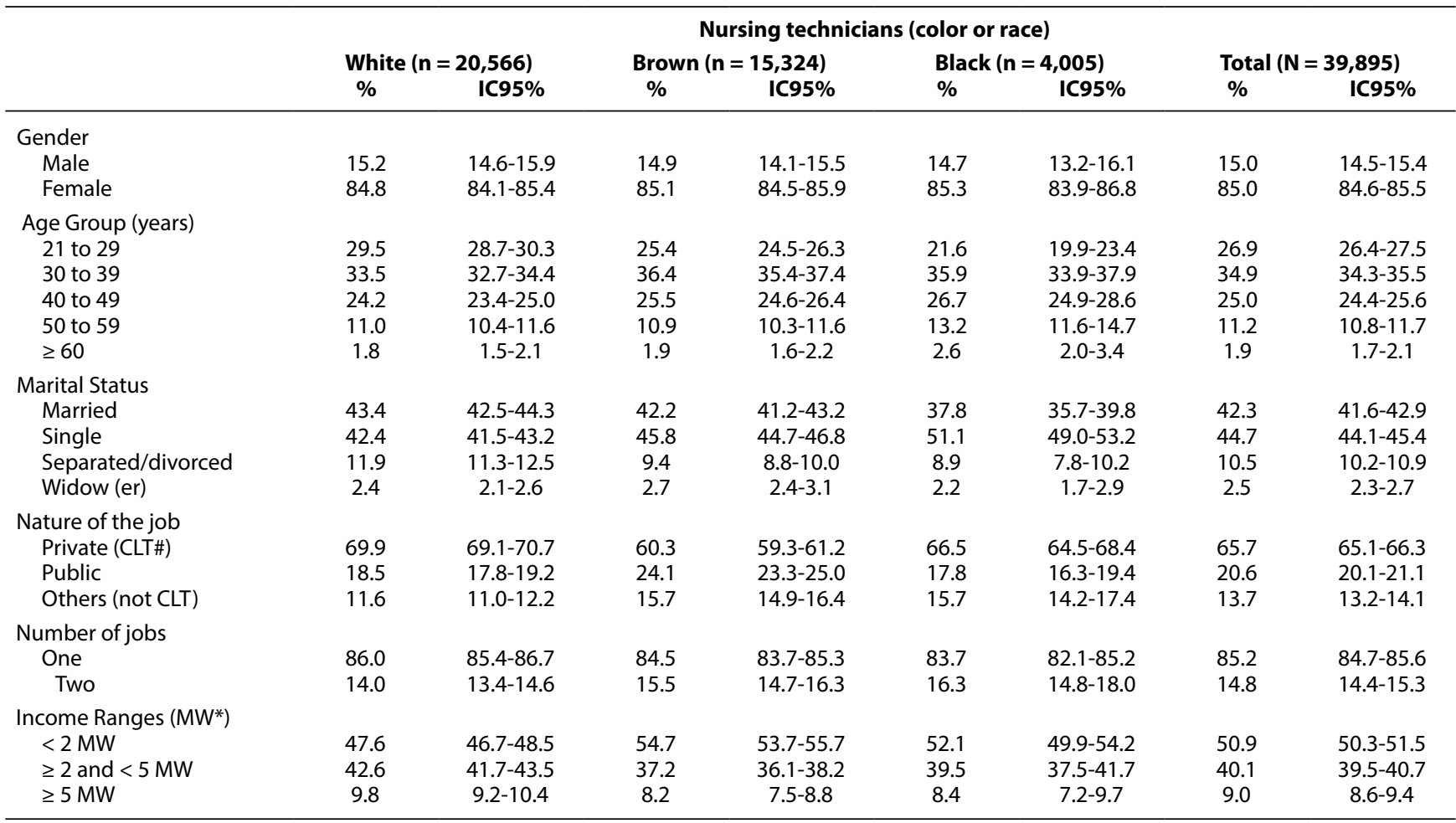

\# CLT - Brazilian Consolidated Labor Laws (guarantee rights to workers through a document called a "work permit"); * MW-Minimum wages: On the reference date of the Census (July 31,2010$)$, one $M W$ was equal to $R \$ 510.00$.

Source: Demographic Census 2010.

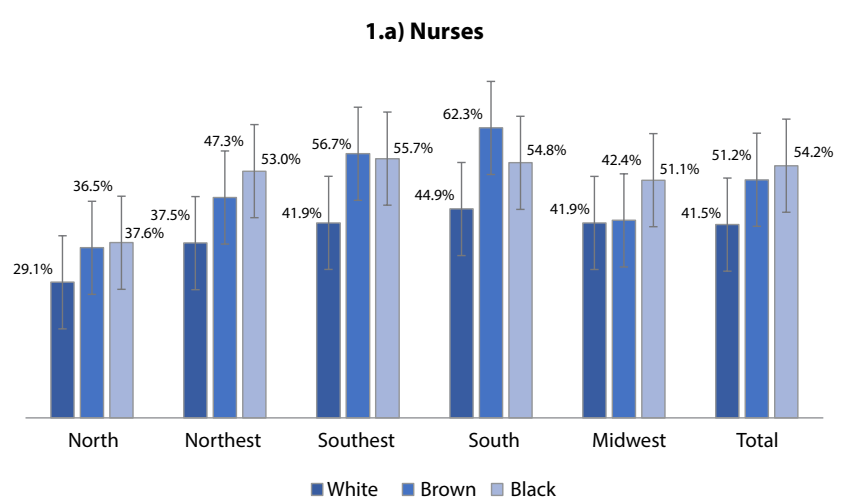

1.b) Nurse technicians

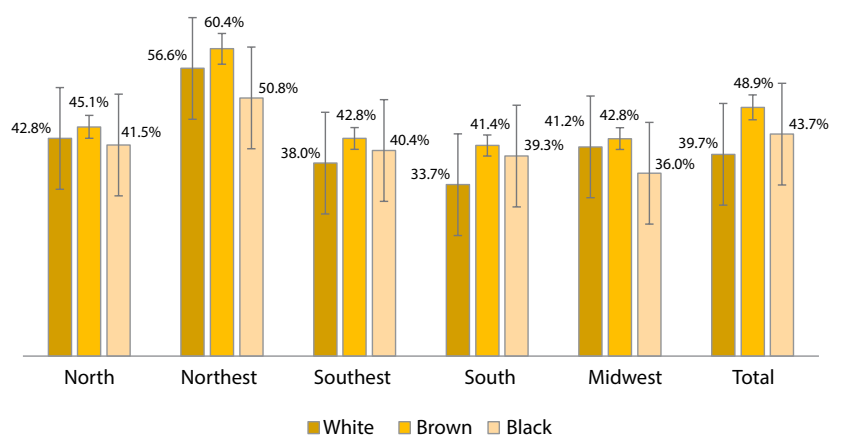

Source: Demographic Census 2010.

Figure 1 - Proportion of nurses (a) and nursing technicians (b) with income below the median value by category of color or race according to large regions, Brazil, 2010
The contingents of nursing technicians living in the Brazilian regions were analyzed by allocating those who declared monthly income lower than $\mathrm{R} \$ 1,000.00$ (value of the median monthly income), characterizing this segment as the one with the lowest income (Figure 1.b). It is noteworthy that only in the Northeast Region was found nursing technicians of the three categories of color or race (white, brown, and black) mostly allocated to the segment with the lowest income $(>50 \%)$. All categories of color or race registered contingents lower than $50 \%$ in the other regions, demonstrating relative homogeneity in income conditions among nursing technicians, regardless of racial background (Figure 1.b).

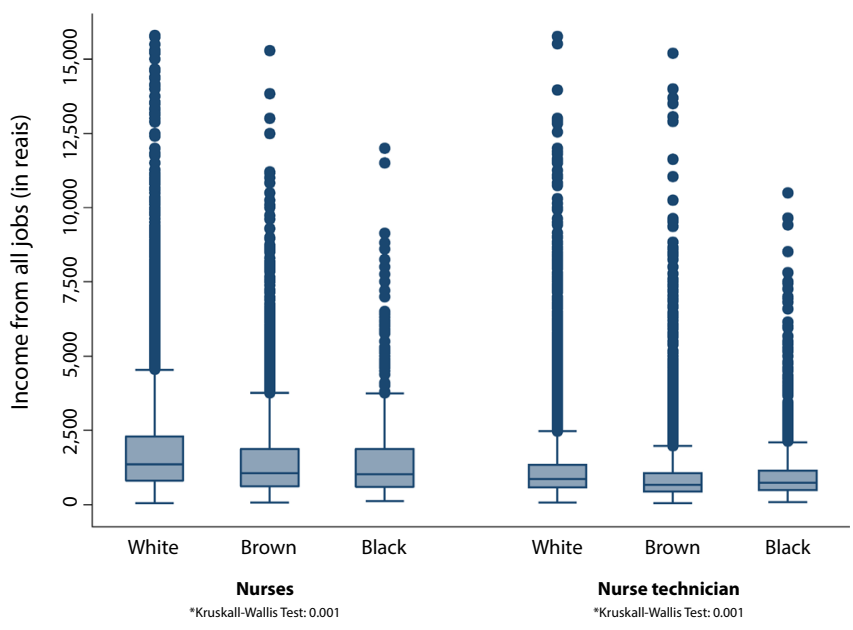

Source: Demographic Census 2010.

Figure 2 - Box-plot of monthly income per capita in Reais of nurses and nursing technicians according to color/race groups, Brazil, 2010 
Table 3 - Inequalities of monthly income per capita of nurses and nursing technicians according to color or race (reference - white color or race), Brazil, 2010

\begin{tabular}{|c|c|c|c|c|c|}
\hline & & \multicolumn{2}{|c|}{ Gross Estimate } & \multicolumn{2}{|c|}{ Adjusted estimate* } \\
\hline & & $\%$ & IC95\% & $\%$ & IC95\% \\
\hline Nurses $(n=22,556)$ & $\begin{array}{l}\text { Brown vs. White } \\
\text { Black vs. White }\end{array}$ & $\begin{array}{l}-23.1 \\
-28.3\end{array}$ & $\begin{array}{l}(-25.1 ;-21.0) \\
(-31.4 ;-25.2)\end{array}$ & $\begin{array}{l}-23.1 \\
-28.4\end{array}$ & $\begin{array}{l}(-25.6 ;-20.6) \\
(-32.1 ;-24.6)\end{array}$ \\
\hline Nursing Technicians $(\mathrm{n}=39,895)$ & $\begin{array}{l}\text { Brown vs. White } \\
\text { Black vs. White }\end{array}$ & $\begin{array}{l}-21.0 \\
-17.0\end{array}$ & $\begin{array}{l}(-22.0 ;-18.9) \\
(-19.6 ;-14.3)\end{array}$ & $\begin{array}{l}-12.8 \\
-11.6\end{array}$ & $\begin{array}{c}(-14.3 ;-11.3) \\
(-13.7 ; 9.3)\end{array}$ \\
\hline Total $(\mathrm{N}=60,936)$ & $\begin{array}{l}\text { Brown vs. White } \\
\text { Black vs. White }\end{array}$ & $\begin{array}{l}-25.8 \\
-25.7\end{array}$ & $\begin{array}{l}(-27.0 ;-24.0) \\
(-27.8 ;-23.0)\end{array}$ & $\begin{array}{l}-21.5 \\
-23.4\end{array}$ & $\begin{array}{l}(-22.7 ;-20.3) \\
(-25.1 ;-21.7)\end{array}$ \\
\hline
\end{tabular}

*Estimates generated by multivariate linear regression models adjusted for gender, age group in years, marital status, geographic region, number of jobs, and nature of the job (public, private, or other). Source: Demographic Census 2010.

According to color or race categories, the patterns of monthly income for nurses and nursing technicians are in Figure 2. The most significant differences in monthly income according to color or race are among nurses, with those of white color/race registering a median monthly income equal to $\mathrm{R} \$ 1,800.00$ (maximum of $\mathrm{R} \$ 15,000.00$ ), while brown and black registered a median income of 1,500.00, with maximum values equal to $R \$ 15,000.00$ and $R \$ 11,800.00$, respectively. Among nursing technicians, income seems to be more homogeneous among the categories of color or race, with the median income for white and black professionals equal to $\mathrm{R} \$ 1,000.00$; and for brown technicians, equal to $\mathrm{R} \$ 900.00$ (Figure 2)

Models created using multivariate linear regression techniques estimate the magnitudes of relative variations in monthly income among nursing professionals according to color or race categories. With white professionals as a reference, income differences were analyzed by transforming the coefficients into percentages. The negative signs express that the monthly incomes of white professionals were always more advantageous than the incomes of brown and black professionals (Table 3 ).

There were no differences in the variation of incomes (gross and adjusted) of brown and white nurses, indicating that the monthly income reported by whites was approximately $23 \%$ higher than brown nurses. However, the income of black nurses was $28 \%$ lower than white nurses, indicating more expressive inequality. In the case of nursing technicians, we observe less favorable situations between brown and black professionals, even though the magnitudes are smaller compared to nurses. Also, with relation to technicians, although the adjusted analyses have reduced the magnitudes of inequality, those of white color or race remained with high chances of having more advantageous incomes than brown and black professionals (Table 3).

\section{DISCUSSION}

Worldwide, the sociodemographic profiles of nursing professionals reveal that it is a predominantly female profession ${ }^{(21)}$ and that, over the last decades, the participation of different racial-ethnic groups has been increasing ${ }^{(1,22)}$. In the case of Brazil, between the years 2000 and 2010, there was an increase of approximately $8 \%$ in the portion of nursing workers who recognized themselves as black (black + brown), which represents a social phenomenon filled with symbolism, since it reflects movements of social mobility and inclusion in spaces previously occupied by white people $e^{(2,4-5)}$. On the other hand, as demonstrated, this phenomenon was related to situations that express socioeconomic inequalities
- inequalities that varied according to the racial background of nursing professionals.

Depending on the categories of color or race of the allocation, nurses and nursing technicians presented different age compositions, work bonds, and income levels, with particular scenarios according to the country's different regions. In general, nurses were primarily white, young, single, and in the higher income strata, while most nursing technicians were brown, belonging to the older age groups and lower-income revenue, and these characteristics were more expressive in those regions of Brazil with lower socioeconomic development indexes.

As a profession in the health field, the history of nursing in Brazil is known by its technical/social and gender division. Since its origin is associated with a female job, and the labor activities are socially undervalued, according to the role assigned to women by a society marked by structural gender and class inequalities ${ }^{(21-22)}$.The division of labor is associated with the division of classes, with attributions at the average level of most of the work and lowest wages. This division was legitimized since Florence Nightingale, the forerunner of the nursing profession, segregated the job in nurses and lady-nurses ${ }^{(21)}$.

As mentioned, the dynamics that characterize the labor markets, including nursing, are influenced by each country's political, economic, and social structures, health care models, and workers' participation in the formulation of policies both in the care and educational context ${ }^{(23-24)}$.

In the case of Brazil, the implementation of the Unified Health System (SUS) in the early 1990s led to a significant expansion of access to health care to a great part of the population, generating increased demand for jobs and the need to prepare professionals for the public system ${ }^{(24)}$. However, this process occurred too fast, with the strong participation of private educational institutions encouraged by government policies to support university education and meet the market demand (supply of professionals), but without proper governmental regulation ${ }^{(24-28)}$.

According to the Ministry of Education, the undergraduate nursing courses jumped from 106 to 799 between 1991 and 2011, representing a growth of $754 \%$ in $\mathrm{Brazi}^{(29)}$. The increase in private institutions was around 65\%, concentrated in the Southeast and South regions ${ }^{(5,28-29)}$. Over the years, there is a significant expansion of technical and higher education courses and jobs in nursing, predominantly private, including at night, in large urban centers, associated with the non-expansion of jobs and unemployment professional and salary devaluation ${ }^{(28-29)}$.

In the present study, income inequalities were evident between technicians and nurses. In both cases, white color or race presented 
higher income levels than black and brown skin color or race. It is noteworthy that the levels of inequality according to racial categories were more expressive among nurses. In other words, although present, income inequalities among white, brown, and black nursing technicians occurred with less magnitude. There is, therefore, evidence that nursing is composed of two groups with different income conditions; consequently, when seeking to investigate the living and working conditions of nursing workers, the stratification of nurses and technicians may be a fundamental strategy to control biases.

One aspect to be considered in the analyses of income inequalities concerns the changes in wage values and purchasing power over time. According to economic indicators, Brazil is characterized as a country with high inflation rates, currency devaluation, and consequent decline in purchasing power (above $80 \%$ in the last 26 years) ${ }^{(18)}$. Among health care workers, the economic impact may have been more expressive since, for most of them, salary adjustments occur through collective agreements instead of being made by linking them to the immediate increase in the minimum wage, which causes losses over time ${ }^{(18,22)}$. Thus, if in 2010, brown and black nursing professionals already had lower income levels compared to white professionals, it is valid to assume that the maintenance of these racial inequalities in socioeconomic status over the decade may have generated and perpetuated negative impacts on living and health conditions, perpetuating the trajectory of vulnerabilities across generations ${ }^{(22)}$.

The composition of the population influences the racial composition of nursing professionals. In Brazil, it differs among regions, with a higher concentration of white people in the South and Southeast and black and brown people in the Northeast and North regions ${ }^{(11)}$. It is important to consider regional inequalities in the country, which have shaped in the course of history ${ }^{(12-13,15)}$ for sociodemographic analyses. Despite the scarcity of references supporting such results, regional inequalities among professionals according to color or race describe a pattern that exposes black and brown nurses and technicians to less favorable income situations in all Brazilian regions.

Historically, brown and black women tend to occupy spaces of lower social status, based on the hierarchy of the labor market (which has been noted with nursing technicians and assistants); while the image of the "standard nurse," at the top of the pyramid, has been crystallized by the elitization and whitening people of the profession ${ }^{(4,22,30)}$. Over the years, professional relationships in the nursing field were represented by a labor dichotomy, in which the nurses responsible for teaching, coordinating, and supervising the job were those with higher socioeconomic status, while those who performed the care were from less favored classes, alluding to the separation between manual and intellectual labor ${ }^{(31-32)}$.

As mentioned, the processes that characterize nurses' job is described as hierarchical and segmented, in constant competition between other members of the nursing team and other health professionals ${ }^{(31)}$. Such aspects are even more evident from the perspective of social relations established by racial inequalities and are present in several countries ${ }^{(33-34)}$.

Indeed, the complexities involved in investigating socioeconomic inequalities in specific occupational categories, such as those addressed in this study, are recognized. These initiatives seek to converge"quantitative empirical analyses carried out using representative databases" with "particular social phenomena." In this way, demographic censuses represent one of the tools that can help understand socioeconomic inequalities evident at the most diverse levels of society, including the labor market ${ }^{(15)}$.

\section{Study limitations}

Some limitations present in this study are reflected in the nature of the population census, especially regarding the categories investigated. The cross-sectional design prevents analysis of temporality effects and the associations' direction with some of the variables included in the models. Data on job and income were referred to by the interviewees; although income is usually underestimated, this condition does not change the direction of the observed associations since the differences in income could be even more significant.

In a broader debate, which goes beyond the theoretical scope of this study, are the categories investigated in the professions. In 2010, there were no professionals recognized as nursing assistants in the Censo Demográfico (Demographic Census) conducted in Brazil, for example.

\section{Contributions to the Fields of Nursing, Health or Public Policy}

The analyses presented in this study are unprecedented. They are essential for a series of aspects, among which are the uniqueness of the results, which present differences in income of nursing workers, stratified according to racial categories (color or race) used by the instruments adopted in the bureaucratic routines in Brazil; the representativeness of the data, collected in all municipalities of the country; and the focus on socioeconomic inequalities, with emphasis on stratifications by color or race. The present initiative inaugurates a debate that has been little explored in demographic dynamics and the sociology of professions, specifically in Brazilian nursing.

\section{CONCLUSIONS}

Analyses on socioeconomic inequalities modulated according to the racial background are essential and, in this study, highlighted the diversity of situations for the same professional category. Also, they are even more relevant in the current context, since 2020 is the bicentennial year of Modern Nursing, in allusion to the birth of Florence Nightingale (1820-1910), the precursor of the axioms of the profession in the West. It is the recognition, by the World Health Organization (WHO) ${ }^{(1)}$, of these two centuries of nursing professionalization. It is worth noting that, in Brazil, the number of nurses and nursing technicians' points in this direction since it reaches about $60 \%$ of all healthcare workers.

This study suggests that in Brazil at the beginning of the $21 \mathrm{st}$ century, racial inequalities persist regarding socioeconomic status even among workers of the same professional category. The social division of labor that employs nursing technicians in the most minor appreciated functions in health systems also places them in the worst income condition. The findings showed that brown and black nursing technicians were the groups with the lowest income levels, and these inequalities aggravate by being even more significant in the more impoverished regions of the country. 


\section{REFERENCES}

1. World Health Organization-WHO. State of the world's nursing 2020: investing in education, jobs and leadership. Geneva: World Health Organization [Internet]. 2020 [cited 2020 Sep 25]. Available from: https://www.who.int/publications-detail/nursing-report-2020

2. Moreira MCN. The Rockefeller Foundation and the construction of a professional identity in nursing during Brazil's First Republic. Hist Cienc Saude-Manguinhos. 1999;5(3):621-45. https://doi.org/10.1590/S0104-59701999000100005

3. Passos E. De anjos a mulheres: ideologias e valores na formação de enfermeiras. 2 ed. Salvador: EDUFBA, 2012.

4. Ferreira LO, Salles RBB. A origem social da enfermeira padrão: o recrutamento e a imagem pública da enfermeira no Brasil, 1920-1960. Nuevo Mundo Mundos Nuevos. 2019. https://doi.org/10.4000/nuevomundo.77966

5. Marinho GL, Paz EPA, Jomar RT, Abreu AMM. Brazilian nurses' sociodemographic changes in the first decade of the 21st century. Esc Anna Nery. 2019;23(1):e20180198. https://doi.org/10.1590/2177-9465-ean-2018-0198

6. Machado MH, Oliveira E, Lemos W et al. Mercado de trabalho da enfermagem: aspectos gerais. Enferm Foco. 2016;7 (ESP):35-62. https://doi. org/10.21675/2357-707X.2016. v7.nESP.691.

7. Machado MH, Koster I, Aguiar-Filho W et al. Labor market and regulatory processes - Nursing in Brazil. Ciênc Saúde Colet. 2020;25(1):101112. https://doi.org/10.1590/1413-81232020251.27552019

8. Instituto Brasileiro de Geografia e Estatística (IBGE). Censo Demográfico 2010. Resultados do Universo. Sistema de Recuperação Automática - SIDRA[Internet]. 2020 [cited 2020 Sep 07]. Available from: www.sidra.ibge.gov.br

9. Fernandes JD, Teixeira GAS, Silva MG, Florêncio RMS, Silva RMO, Rosa DO. Expansion of higher education in Brazil: increase in the number of undergraduate nursing courses. Rev Latino-Am Enfermagem, 2013;21(3):670-8. https://doi.org/10.1590/S0104-11692013000300004

10. Campante FR, Crespo ARV, Leite PG. Desigualdade salarial entre raças no mercado de trabalho urbano brasileiro: aspectos regionais. Rev Bras Econ. 2004;58(2):185-210. https://doi.org/10.1590/S0034-71402004000200003

11. Telles EE. O significado da raça na sociedade brasileira. Princeton e Oxford: Princeton University Press; 2004.

12. Silva GM, Paixão M. Mix and Unequal: new perspectives on Brazilian Ethnoracial Relations. In: Telles E, ed. Pigmentocracies - Ethnicity, race, and color in Latin America. USA:The University of North Carolina Press; 2014.

13. Telles EE. Race in another America: the significance of skin color in Brazil. New Jersey: Princeton University Press; 2002.

14. Lombardi MR, Campos VP. A Enfermagem e os contornos de gênero, raça/cor e a classe social na formação do campo profissional. Rev ABET. 2018 (17):28-46. https://doi.org/10.22478/ufpb.1676-4439.2018v17n1.41162

15. Kertzel DI, Arel D. Census and identity: the politics of race, ethnicity, and language in national censuses. Cambridge: Cambridge University Press; 2002.

16. D'Antonio P, Whelan JC. Counting nurses: the power of historical census data. J Clin Nurs, 2009;18(19):2717-24. https://doi. org/10.1111/j.1365-2702.2009.02892.x

17. Instituto Brasileiro de Geografia e Estatística (IBGE). Metodologia do Censo Demográfico 2010. Rio de Janeiro: Instituto Brasileiro de Geografia e Estatística [Internet]. 2013 [cited 2020 Sep 07]. Available from: https://biblioteca.ibge.gov.br/visualizacao/livros/liv95987.pdf

18. Departamento Intersindical de Estatística e Estudos Socioeconômicos (DIEESE). Análise cesta básica [Internet]. 2021 [cited 2020 Sep 07]. Available from: https://www.dieese.org.br/analisecestabasica/salarioMinimo.html

19. Chein F. Introdução aos modelos de regressão linear: um passo inicial para compreensão da econometria como uma ferramenta de avaliação de políticas públicas. Brasília: Enap; 2019.

20. Malta M, Cardoso LO, Bastos FI, Magnanini MMF, Silva CMFP. STROBE initiative: guidelines on reporting observational studies. Rev Saude Publica. 2010;44(3):559-65. https://doi.org/10.1590/S0034-89102010000300021

21. Dias MJS. Feminização do trabalho no contexto da reestruturação produtiva: rebatimentos na saúde pública. São Luís: Edufma, 2009.

22. Melo CMM. Divisão social do trabalho e enfermagem. São Paulo: Cortez; 1986.

23. Oliveira JS, Pires DEP. Tendências do mercado de trabalho para enfermeiros(as): cenário internacional e do Nordeste brasileiro. Belo Horizonte: Ramalhete; 2018.

24. Mendonça MHM, Matta GC, Gondim R, Giovanella L (Orgs.). Atenção Primária à Saúde no Brasil: conceitos, práticas e pesquisa. Rio de Janeiro: Editora Fiocruz; 2018.

25. Silva KL, Cabral IE. National Licensure Exam for Brazilian Nurses: why and for whom? Rev Bras Enferm, 2018;71(4):1692-9. https://doi. org/10.1590/0034-7167-2017-0929

26. Machado MH. Perfil da enfermagem no Brasil: relatório final. Rio de Janeiro: Nerhus/Fiocruz; 2017.

27. Pierantoni CR, França T, Magnago C. Graduações em saúde no Brasil: 2000- 2010. Rio de Janeiro: Cepesc, 2012.

28. Ministério da Educação (BR). Instituto Nacional de Estudos e Pesquisas Educacionais Anísio Teixeira. Censo da Educação Superior 2010. Divulgação dos principais resultados do Censo da Educação Superior 2010. Brasília [Internet]. 2011 [cited 2020 Sep 07]. Available from: http://download.inep.gov.br/educacao_superior/censo_superior/documentos/2010/divulgacao_censo_2010.pdf 
29. Pierantoni CR, Magnago C. Tendências das graduações em Saúde no Brasil: análise da oferta no contexto do Mercosul. Divulg Saúde Debate. 2017;(57):30-43.

30. Campos P. As enfermeiras da Legião Negra: representações da enfermagem na revolução constitucionalista de 1932. Faces de Eva: Estudos sobre a Mulher [Internet]. 2015[cited 2020 Sep 20];33:53-65. Available from: https://scielo.pt/pdf/eva/n33/n33a07.pdf

31. Soares CB, Souza HS, Campos CMS. Processos de trabalho em enfermagem: uma contribuição a partir da saúde coletiva. In: Souza HS, Mendes A. (Orgs.). Trabalho e saúde no capitalismo contemporâneo: enfermagem em foco. Rio de Janeiro: 2016. p. 43-61.

32. Maas LWD. Análise comparativa da base social da Medicina e Enfermagem no Brasil entre os anos de 2000 e 2010. Cad Saúde Pública. 2018;34(3):e00199116. https://doi.org/10.1590/0102-311x00199116

33. Xue Y, Brewer C. Racial and Ethnic Diversity of the U.S. National Nurse Workforce 1988-2013. Policy Polit Nurs Pract. 2014;15(3-4):102-10. https://doi.org/10.1177/1527154414560291

34. Leal JAL, Melo CMM. The nurses' work process in different countries: an integrative review. Rev Bras Enferm, 2018;71(2):413-23. https://doi. org/10.1590/0034-7167-2016-0468 